\title{
An audit of obstetric admissions to intensive care unit in a medical college hospital of central India: lessons in preventing maternal morbidity and mortality
}

\author{
Manisha Jain*, Jyoti Nath Modi
}

Department of Obstetrics \& Gynaecology, People's College of Medical Sciences \& Research Centre, Bhopal- 462037, Madhya Pradesh, India

Received: 05 December 2014

Accepted: 19 December 2014

\section{*Correspondence:}

Dr. Manisha Jain,

E-mail: mnishu2002@yahoo.com

Copyright: (C) the author(s), publisher and licensee Medip Academy. This is an open-access article distributed under the terms of the Creative Commons Attribution Non-Commercial License, which permits unrestricted non-commercial use, distribution, and reproduction in any medium, provided the original work is properly cited.

\begin{abstract}
Background: The spectrum of causes leading to maternal morbidity and mortality may be well reflected in the clinical profile of obstetric patients admitted to the Intensive Care Unit (ICU). An audit of these patients may help in devising intervention strategies and implementing preventive measures. This is expected to contribute to the ongoing concerted multipronged efforts towards reducing maternal mortality as a step towards the millennium development goals. The aim was to study the clinical and demographic profile of antenatal and postpartum women requiring admission to the ICU, the interventions required in these women and the final outcome. The overall goal is to identify the contributing factors towards maternal morbidity and mortality.

Methods: A retrospective analysis of hospital records of all antenatal, post-abortal and postpartum women admitted to the ICU at People's hospital, Bhopal over a period of 3 years (June 2011 to May 2014).

Results: A total of 157 records were identified and analyzed: 22 (14\%) antenatal, seven (4\%) post-abortion, 114 (73\%) postpartum, and 14(9\%) post-laparotomy women. The mean age was 25 years (Range 18-38 years; SD 4.49), two thirds being from rural areas. Majority $(78 \%)$ had no earlier visit. The gestational age at admission to ICU ranged from 6-43 weeks (Mean 31 weeks; SD 9.06). One third (24\%) of patients had severe anemia, 18 patients needed ventilation, 25 required inotropic support, 4 required dialysis and 17 underwent surgical intervention. Blood or blood component therapy was needed in $60 \%$ cases with total blood units transfused being 225 . The average duration of stay in intensive care unit was 79 hours. Analyzing as organ-system dysfunctions: Cardiovascular dysfunction (22\%), hematological $(20 \%)$, hepatic $(16 \%)$, neurological $(11 \%)$, septicemia $(11 \%)$, renal $(9 \%)$. There were 19 maternal deaths.

Conclusions: Maternal anemia and consequences still contribute significantly to maternal morbidity. Non-utilization of antenatal care services especially in rural area compounds the problem. Multidisciplinary care is essential in intensive care setting.
\end{abstract}

Keywords: Obstetric, Intensive care unit, Maternal mortality

\section{INTRODUCTION}

Pregnancy is a period of joy for the mother and family while maternal death is an unfortunate and tragic event. Severe life threatening complications can occur during or after pregnancy with little or no advance warning. Reduction in maternal mortality ratio by $75 \%$ (109) has been an important millennium development goal to be achieved by 2015. Though India has registered a significant fall in maternal mortality (MMR 178 in 2010 - 
12), ${ }^{1}$ our progress is quite slow. Problem is worse in eight Empowered Action Group (EAG) states with incomplete vital registries and significant under reporting of cases. It is unfortunate that many of the maternal deaths largely remain silent in our country.

The need for accurate monitoring and record keeping of maternal mortality has always been realized to formulate the policies, to accelerate the progress and for proper allocation of resources. As many maternal deaths go unnoticed and untold, the study of severe obstetric morbidity (Near miss) has emerged as an important indicator of comprehensive obstetric care complementing the study of maternal death. Maternal "Near miss" is defined as a woman who nearly died but survived a complication that occurred during pregnancy, childbirth or within 42 days of termination of pregnancy.

While maternal mortality represents the tip of iceberg, severe maternal morbidity survivors or near miss cases form the broad base and help identify women at highest risk of maternal death. Study of near miss cases helps to triage essential obstetric care towards more needy women in limited resource settings. Obstetric admissions to intensive care unit is a well-established criteria (WHO) to identify severe obstetric morbidity and an audit of obstetric ICU admissions can help devise intervention strategies and implement preventive measures. The aim of this retrospective analysis was to study the clinical and demographic profile of pregnant and puerperal women admitted to intensive care unit at our centre, the interventions carried out in these women and the final outcome. The overarching goal is to identify the contributing factors towards maternal morbidity and mortality in our setting.

\section{METHODS}

The present study was undertaken in the Department of Obstetrics and Gynaecology at a medical college hospital of Central India. This is a retrospective analysis of hospital records of all antenatal, post-abortal and postpartum women who got admitted to the medical or surgical ICU for various reasons over a period of 3 years (June 2011 to May 2014). After approval by institutional research advisory committee and ethics committee, all pregnant women irrespective of their gestational age and women within 42 days of delivery who required admission to intensive care unit were included in the study. The records of these women were analyzed to note the demographic details, parity, reasons for ICU admission, organ system involvement, interventions required by them, the final maternal outcome and the various contributory factors for maternal mortality.

The causes for which women required to be admitted in intensive care unit were identified as severe preeclampsia, eclampsia, HELLP syndrome, severe haemorrhage, sepsis and various organ system dysfunction or women requiring massive blood transfusions, ventilation, dialysis or major surgical intervention. Maternal deaths were classified into three groups based on the underlying causes. The maternal deaths resulting from obstetric complication of pregnant state (pregnancy, labour and puerperium) from interventions, omissions or incorrect treatment or from a chain of events resulting from any of the above were classified as the direct obstetric deaths. Maternal deaths resulting from previous existing disease or disease that developed during pregnancy and that was not due to direct obstetric cause but was aggravated by the physiological effects of pregnancy were grouped into indirect obstetric deaths. Deaths of woman resulting from accidental or incidental causes were classified as due to non-obstetric causes. Maternal deaths during first 20 weeks of pregnancy were grouped into early pregnancy deaths while those occurring after 20 weeks were called as late maternal deaths. The data thus obtained were analyzed using fractional percentage and other descriptive analytical methods.

\section{RESULTS}

A total number of 157 records of women admitted to intensive care unit over a period of three years from June 2011 to May 2014 were analyzed. As the facility for obstetric ICU is not available at our centre, the data were taken of pregnant, postpartum or postabortal women admitted to medical or surgical ICU for various indications. The total number of deliveries during the period were 2906 while total number of maternal deaths were nineteen.

\section{Demographic characteristics}

The majority of women were young with seven (4.4\%) cases of teenage pregnancy. About two-thirds of women with severe morbidity at the time of admission were unbooked and had no prior antenatal visit. In our study, about half of women belonged to rural $(57.3 \%)$ areas and about half had their index pregnancy (49\%). Most of the women admitted to ICU were in later half of pregnancy or postpartum with a mean gestational age for all being 31.35 weeks. Anaemia in pregnancy continues to be a major killer with $103(66 \%)$ cases having co- existent moderate or severe anemia (Table 1).

Table 1: The demographic characteristics of women admitted to ICU $(n=157)$.

\begin{tabular}{|lll|}
\hline \multicolumn{2}{|l|}{ The demographic characteristics } \\
\hline Maternal age & Range: $18-38$ years & Mean $25.57 \pm 4.49$ \\
\hline Booking status & $\begin{array}{l}122(77.7 \%) \\
\text { unbooked }\end{array}$ & $35(22.2 \%)$ booked \\
\hline Residence & $90(57.3 \%)$ rural & $67(42.6 \%)$ urban \\
\hline Parity & $77(49 \%)$ primi & $80(51 \%)$ multi \\
\hline Gestational age & Range: $6-43$ weeks & Mean $31.35 \pm 9.06$ \\
\hline $\begin{array}{l}\text { Haemoglobin } \\
(\text { gm/dl) }\end{array}$ & $\begin{array}{l}\text { Range: } 1.4 \text { gm\%- } \\
11.5 \text { gm } \%\end{array}$ & Mean 8.44 gm $\%$ \\
\hline
\end{tabular}


At the time of ICU admission 114 (73\%) cases were in postpartum period.

Included among them were the women who got delivered at other peripheral centres and then got referred to our centre in critical condition (Table 2).

Table 2: Distribution of cases according to pregnancy status at the time of ICU admission.

\begin{tabular}{|llll|}
\hline Gestational period & $\begin{array}{l}\text { Total No. } \\
\text { (percentage) }\end{array}$ & $\begin{array}{c}\text { Total } \\
\text { No. }\end{array}$ \\
\hline Antepartum & $22(14 \%)$ & 34 \\
\hline Postpartum & $114(72.6 \%)$ & $\begin{array}{l}\text { Post vaginal } \\
\text { delivery }\end{array}$ & $\begin{array}{l}\text { Post LSCS/ } \\
\text { hysterectomy }\end{array}$ \\
\hline $\begin{array}{l}\text { Post evacuation } \\
\text { (abortion /v mole) }\end{array}$ & $07(4.4 \%)$ & \\
\hline Post laparotomy & $14(9 \%)$ & \\
\hline Total & $\mathrm{N}=157$ & \\
\hline
\end{tabular}

\section{Organ system dysfunctions}

Analyzing as organ-system dysfunctions, cardiovascular dysfunctions (22\%), hematological $(20 \%)$, hepatobiliary (16\%), neurological (11\%), and septicemia (11\%) were the leading medical causes for ICU admission. Twenty three $(15 \%)$ women had multi-organ involvement necessitating multi-disciplinary approach. Specific infections like tuberculosis (4), malaria (9) and hepatitis (3) were seen in significant number of cases (Table 3 ).

Table 3: Organ system dysfunction requiring ICU admission $(n=157)^{*}$.

\begin{tabular}{|lll|}
\hline Organ system involved & No. & $\begin{array}{l}\text { Percentage } \\
(\%)\end{array}$ \\
\hline Cardiovascular & 35 & $22.2 \%$ \\
\hline $\begin{array}{l}\text { Haematological/ } \\
\text { Thrombocytopenia }\end{array}$ & 30 & $20 \%$ \\
\hline Hepatobiliary, GI & 26 & $16.5 \%$ \\
\hline Neurological & 18 & $11.4 \%$ \\
\hline Septicaemia & 18 & $11.4 \%$ \\
\hline DIC, coagulopathy & 14 & $8.9 \%$ \\
\hline Renal & 14 & $8.9 \%$ \\
\hline ARDS, pulmonary & 07 & $4.4 \%$ \\
\hline Embolism & 06 & $3.8 \%$ \\
\hline Metabolic/burns & 03 & $1.9 \%$ \\
\hline $\begin{array}{l}\text { Specific infections } \\
\text { (T.B., malaria, HCV, }\end{array}$ & 16 & $10.1 \%$ \\
HBsAg, HEV etc.) & & $14.6 \%$ \\
\hline Multiorgan dysfunction & 23 & \\
\hline
\end{tabular}

*Many had more than one organ involvement

As rupture uterus and obstructed labour become less frequent, hypertensive disorders of pregnancy (54\%) and obstetric hemorrhage (27\%) have emerged as the two most common obstetric reasons for ICU admission.

Ruptured ectopic, vesicular mole, abortion related hemorrhage were responsible for admission at early gestation (Table 4).

Table 4: The obstetric causes requiring ICU admission among 157 women.

The obstetric causes requiring ICU admission

\begin{tabular}{|c|c|c|c|}
\hline \multicolumn{4}{|c|}{ Hypertensive disorders of pregnancy } \\
\hline \multirow{3}{*}{$85(54 \%)$} & Severe preeclampsia & 62 & \multirow{3}{*}{85} \\
\hline & Eclampsia & 15 & \\
\hline & HELLP syndrome & 08 & \\
\hline \multicolumn{4}{|c|}{ Obstetric haemorrhage } \\
\hline \multirow{5}{*}{$43(27 \%)$} & Ectopic & 12 & \multirow{3}{*}{20} \\
\hline & MTP / abortion & 05 & \\
\hline & Vesicular mole & 03 & \\
\hline & Antepartum haemorrhage & 16 & \multirow{2}{*}{23} \\
\hline & Postpartum haemorrhage & 07 & \\
\hline $\begin{array}{l}\text { Severe } \\
\text { sepsis }\end{array}$ & $18(11.4 \%)$ & & \\
\hline $\begin{array}{l}\text { Rupture } \\
\text { uterus }\end{array}$ & 02 & & \\
\hline $\begin{array}{l}\text { Obstructed } \\
\text { labour }\end{array}$ & 02 & & \\
\hline
\end{tabular}

\section{Characteristics of ICU stay}

The duration of stay in intensive care unit ranged from 50 min to 416 hours (Mean 78.62 hours). About one-third $(28 \%)$ of cases were admitted in ICU for less than 48 hours while majority of maternal deaths $(42 \%)$ occurred during this period.

One hundred and two women $(65 \%)$ women required prolonged admission in ICU for more than 72 hours (Table 5).

Table 5: The duration of ICU stay in relation to maternal deaths.

\begin{tabular}{|lllll|}
$\begin{array}{l}\text { Duration of } \\
\text { ICU stay }\end{array}$ & $\begin{array}{l}\text { No. of } \\
\text { women }\end{array}$ & $\%$ & $\begin{array}{l}\text { No. of } \\
\text { maternal } \\
\text { deaths }\end{array}$ & $\%$ \\
\hline$<24$ hours & 12 & $7.6 \%$ & 08 & $42 \%$ \\
\hline $24-48$ ours & 32 & $20.3 \%$ & 02 & $10.5 \%$ \\
\hline $48-72$ hours & 11 & $7 \%$ & 02 & $10.5 \%$ \\
\hline$>72$ hours & 102 & $65 \%$ & 07 & $36.8 \%$ \\
\hline Total & $\mathrm{n}=157$ & $\begin{array}{l}\text { Mean: } \\
78.62 \text { hours }\end{array}$ & 19 & \\
\hline
\end{tabular}

Twenty five patients required inotropic support, 18 mechanical ventilation for varied duration, 4 undergone dialysis while 17 underwent surgical intervention as laparotomy (13), obstetric hysterectomy (03) or ileal resection anastomosis for perforation peritonitis. 
Blood and blood components therapy were required by many with total units being transfused as 225 units. [Whole blood (24 units), PRBC (83 units), FFP (65 units), Platelets concentrate (53 units)] (Table 6).

Table 6: The vital supports required during ICU stay.

\begin{tabular}{|c|c|c|c|}
\hline $\begin{array}{l}\text { The support } \\
\text { required }\end{array}$ & $\begin{array}{l}\text { No. of } \\
\text { cases }\end{array}$ & & $\begin{array}{l}\text { No. of } \\
\text { cases }\end{array}$ \\
\hline $\begin{array}{l}\text { Inotropic } \\
\text { support }\end{array}$ & 25 & & \\
\hline $\begin{array}{l}\text { Intubation \& } \\
\text { mechanical } \\
\text { ventilation }\end{array}$ & 18 & & \\
\hline Tracheostomy & 01 & & \\
\hline Dialysis & 04 & & \\
\hline $\begin{array}{l}\text { Blood \& blood } \\
\text { component } \\
\text { therapy }\end{array}$ & $\begin{array}{l}225 \\
\text { units }\end{array}$ & & \\
\hline \multirow{3}{*}{$\begin{array}{l}\text { Surgical } \\
\text { intervention }\end{array}$} & \multirow{3}{*}{17} & $\begin{array}{l}\text { Exploratory laparotomy } \\
\text { haemorrhage, uterine } \\
\text { packing, internal iliac } \\
\text { ligation ) }\end{array}$ & 13 \\
\hline & & Obstetric hysterectomy & 03 \\
\hline & & $\begin{array}{l}\text { Ileal resection } \\
\text { anastomosis }\end{array}$ & 01 \\
\hline
\end{tabular}

\section{Characteristics of mortality cases}

We analyzed the 19 records of patients who expired during the period of study. Almost all cases (17/19) were unbooked and had emergency referral. Eleven had their index pregnancy and majority (17/19) were late maternal deaths i.e. after 20 weeks of pregnancy. Among the 17 late maternal deaths, only 2 were antenatal and rest all postpartum (15 cases). Indirect Obstetric causes (11 cases) predominated over direct obstetric (07 cases) and accidental (01) causes, though anaemia was present in almost all (mean Hb 5.8 gm\%) (Table 7).

Table 7: The characteristics of 19 women with maternal mortality.

\begin{tabular}{|lll|}
\hline The characteristics & Mean: 24.74 years & Range 18-35 years \\
\hline Booking Status & Unbooked (17/19) & Booked $(2 / 19)$ \\
\hline Parity & Primi (11/19) & Multi $(8 / 19)$ \\
\hline Residence & Rural (12/19) & Urban $(7 / 19)$ \\
\hline $\begin{array}{l}\text { Timing of } \\
\text { maternal death } \\
\text { (gestational age) }\end{array}$ & Late $(17 / 19)$ & Early $(2 / 19)$ \\
\hline $\begin{array}{l}\text { Haemoglobin } \\
\text { Duration of ICU } \\
\text { stay }\end{array}$ & Mean: 66.26 gmours $\%$ & $\begin{array}{l}\text { Range: } 1.4 g m \%- \\
10.4 \text { gm } \%\end{array}$ \\
\hline $\begin{array}{l}\text { Death within } 48 \\
\text { h of admission }\end{array}$ & $10 / 19$ & min- \\
\hline Cause of death & Indirect obstetric & Direct obstetric \\
\hline
\end{tabular}

\begin{tabular}{|lll|}
\hline & $(11 / 19)$ & $\begin{array}{l}(07 / 19), \text { accidental } \\
(01)\end{array}$ \\
\hline Fetal outcome & $\begin{array}{l}\text { Pregnancy loss, } \\
\text { neonatal death } \\
(14 / 19)\end{array}$ & Live births $(5 / 19)$ \\
\hline
\end{tabular}

Pregnancy loss or neonatal death was seen in 14 patients. The mean duration of stay in ICU was 66.26 hours with about half $(52 \%)$ of patients getting expired within 48 hours of admission (Table 7).

\section{Contributory factors}

On analyzing the various contributory factors in cases of maternal mortality, delay in seeking medical help (11/19) due to lack of awareness or familial support was most prominent as many reported late at advanced stage. Deliveries by untrained dais (02) and self-administration of MTP ills (01) were responsible for moribund condition of mother in 3 cases (Table 8).

Table 8: Various contributory factors to maternal
mortality.

\begin{tabular}{|c|c|c|}
\hline System & Contributory factor & $\begin{array}{l}\text { No. of } \\
\text { cases }\end{array}$ \\
\hline \multirow{3}{*}{ Personal/family } & Delay in seeking help & 11 \\
\hline & Refusal for admission/treatment & 03 \\
\hline & Lack of funds/attendee & 04 \\
\hline \multirow{2}{*}{$\begin{array}{l}\text { Facilities/logistic } \\
\text { problems }\end{array}$} & Lack of transport & 02 \\
\hline & $\begin{array}{l}\text { Lack of facility / equipment / } \\
\text { blood }\end{array}$ & 04 \\
\hline \multirow{3}{*}{$\begin{array}{l}\text { Health personnel } \\
\text { problems }\end{array}$} & Untrained dais & 02 \\
\hline & Self-administration of MTP pills & 01 \\
\hline & $\begin{array}{l}\text { Lack of surgeons / anaesthetists } \\
\text { / training }\end{array}$ & nil \\
\hline
\end{tabular}

\section{DISCUSSION}

Despite the multipronged efforts all over, maternal mortality continues to be high in India and other developing countries. A "look back" analysis is probably the most promising way to move forward towards the ultimate goal of reducing maternal mortality. The current study involving an audit of obstetric admissions to intensive care unit is one such step.

The majority of women in our study were young (Mean 25 years) with adolescent pregnancies (4\%) being a matter of concern. Yuel Veronica et al. reported the mean age as 27 years which is comparable to our study. ${ }^{2}$ Regular antenatal care continues to be a matter of concern, especially in rural area as $78 \%$ cases had no prior antenatal visit. About two thirds (73\%) of women admitted to ICU were in postpartum period, a period that warrants strict observation, vigilance and care. In the study by Yuel Veronica et al. 64\% were emergency referrals and $50 \%$ were postpartum. ${ }^{2}$ About half (49\%) of women being primigravida, importance of institutional 
delivery at least in index pregnancy cannot be overemphasized. The mean gestational age for all was 31 weeks again stressing upon more frequent antenatal visits in later half of pregnancy. Turkan $\mathrm{T}$ et al. also reported mean gestational age as 35 weeks in their study. ${ }^{3}$ Maternal anaemia (72\%) continues to kill and cripple our mothers despite huge governmental efforts to eradicate anemia.

Cardiovascular dysfunction (22\%), haematological (20\%), hepatobiliary (16\%) neurological (11\%) and sepsis $(11 \%)$ were present in significant number of cases. Multi -organ dysfunction (15\%) not only necessitate a need for multidisciplinary team approach but also for establishment of dedicated obstetric intensive care units. In the study of near miss cases by Disha VS et al. however liver $(31 \%)$, vascular $(28 \%)$ and renal $(15 \%)$ dysfunction were the commonest reason for ICU admission. ${ }^{4}$ Preventable infections like malaria (9 cases), tuberculosis (4 cases) and hepatitis (3 cases) still pose a challenge to our national programmes. Disha VS et al. however noted a higher frequency of hepatitis infection due to presence of epidemic during their study. ${ }^{4}$

Among the obstetrics reasons for ICU admission hypertensive disorders of pregnancy (54\%) and obstetric hemorrhage $(27 \%)$ were the leading causes. Turkan $\mathrm{T}$ et al. and Daniel $\mathrm{O}$ et al. also noted pregnancy induced hypertensive disorders and hemorrhage as the most common causes for ICU admission in their respective studies. ${ }^{3,5}$ The need for strict blood pressure monitoring in antenatal woman and early identification of cases with timely referral cannot be overemphasized. Severe hemorrhage secondary to unsupervised administration of abortifacients and $\mathrm{PPH}$ resulting from deliveries by untrained dais or birth attendants calls for urgent attention and implementation of strict legislative measures. Haemorrhage secondary to ruptured ectopic pregnancy (12 cases) and antepartum hemorrhage (16 cases) contributed significantly to morbid state of the patients in our study. Prompt control of hemorrhage, rapid restoration of blood volume and correction of anemia at the outset of pregnancy can curtail down many such morbidities.

In the current study, the mean duration of stay in ICU was $78.62 \mathrm{hrs}$. About two-thirds of patients stayed in ICU for more than 72 hours however, $50 \%$ of maternal deaths occurred during first 48 hours of admission to ICU. Inotropic support (25 cases), mechanical ventilation (18 cases) and dialysis (04) were the major ICU interventions. Seventeen cases required surgical intervention in various forms [Exploratory laparotomy (13), obstetric hysterectomy (3), ileal resection anastomosis (1)]. The percentage of obstetric patients requiring mechanical ventilation in ICU has been variously reported as $19 \%$ by Selo-Ojeme et al. ${ }^{5}$ and $64 \%$ by Tripathi et al. ${ }^{6}$

Utilization of antenatal services especially in rural areas of country is still a matter of concern. Analyzing the records of 19 women who expired during the period of study, almost all cases (17/19) were emergency referrals with no prior antenatal check-ups. Faponle AF et al. also observed maternal mortality more frequently in unbooked cases $(5 / 7$ cases $)$ in their study. ${ }^{7}$

In our study, majority (17/19) were late maternal deaths insisting upon the need for close monitoring and extra vigilance during the puerperium. Anaemia in pregnancy continues to contribute to maternal mortality significantly with mean $\mathrm{Hb}$ for all cases of mortality being $5.8 \mathrm{gm} \%$. Among the various contributory factors, delay in seeking medical help, lack of family persons to accompany, lack of transport at rural set-ups and ignorance about the disease are common problem need to be addressed urgently. Late reporting and late referrals contribute to missing out on the opportunities. Deliveries by untrained dais and self-administration of abortifacients leading to life threatening complications continue to perplex the health care delivery systems of modern era.

\section{CONCLUSIONS}

Regular antenatal care continues to be challenge especially in rural area. Maternal anaemia continues to contribute significantly to maternal mortality and morbidity. Majority of conditions that contribute to ICU admission are preventable. Social factors such as selfadministration of abortifacients, deliveries by untrained dais, poor referrals and delay in transport need to be addressed urgently. Multidisciplinary approach is a must in intensive care settings.

\section{Funding: No funding sources}

Conflict of interest: None declared

Ethical approval: The study was approved by the institutional research advisory committee and ethics committee

\section{REFERENCES}

1. Special bulletin on maternal mortality in India 201012. Sample Registration System office of Registrar General, India, December 2013. Available at: http://www.censusindia.gov.in/vital_statistics/SRS_ Bulletins/MMR_Bulletin-2010-12.pdf.

2. Yuel V. Irene, Kaur Vaneet, Kaur Gurvinder, Andappam Arun, Afzal Lalita. Critical care in obstetrics- scenario in a developing country. J Obstet Gynaecol India. 2008 May-Jun;58(3):217-20.

3. Turkan Togal, Neslihan Yucel, Ender Gedik, Nurcin Gulhas, H. I. Toprak, M. O. Ersoy. Obstetric admissions to the intensive care unit in a tertiary referral hospital. J Crit Care. 2010;25:628-33.

4. Disha V. Sahijwani, Ajesh Desai, Vijay Kansara. Analysis of near miss cases as a reflection of emergency obstetric services and need of obstetric ICCU. J South Asian Feder Obstet Gynaecol (JSAFOG). 2013 Sept-Dec;5(3):99-101. 
5. Selo-Ojeme DO, Omosaiye M, Battacharjee P, Kadir RA. Risk factors for obstetric admissions to the intensive care unit in a tertiary hospital: a casecontrol study. Arch Gynaecol Obstet. 2005;272:20710.

6. Tripathi R, Rathore AM, Saran S. Intensive care for critically ill obstetric patients. Int J Gynaecol Obstet. 2000;68:257-8.

7. Faponle AF, Adenekan AT. Obstetric admissions into the intensive care unit in a sub-urban university teaching hospital. Nepal J Obstet Gynaecol. 2011 Nov-Dec;6(2):33-6.

DOI: $10.5455 / 2320-1770$. ijrcog20150225

Cite this article as: Jain M, Modi JN. An audit of obstetric admissions to intensive care unit in a medical college hospital of central India: lessons in preventing maternal morbidity and mortality. Int J Reprod Contracept Obstet Gynecol 2015;4:140-5. 